\title{
ANALISIS TEORI NYERI: KESEIMBANGAN ANTARA ANALGESIK DAN EFEK SAMPING
}

\author{
Imami Nur Rachmawati*
}

\begin{abstract}
Abstrak
Teori dalam keperawatan diklasifikasikan dalam grand theory, middle-range theory, dan low range atau practice theory. Pengetahuan tentang practice theory sangat penting bagi seorang perawat dalam melakukan praktik asuhan keperawatan seharihari. Salah satu practice theory yang dikembangkan pada tahun 2000-an adalah berkaitan dengan manajemen nyeri. Artikel ini memberikan gambaran analisis teori nyeri: keseimbangan antara analgesik dan efek samping berdasarkan langkah-langkah yang telah dirumuskan Walker dan Avant sehingga dapat disimpulkan kelebihan dan kekurangan teori tersebut.
\end{abstract}

Kata kunci: analisis teori, manajemen nyeri

\section{Abstract}

Theories in nursing are classified into grand theory, middle-range theory, and low range or practice theory. In the daily practice, it is important for a nurse to understand and apply nursing theory. One of the practice theory introduced in 2000-s is related to pain management. The aim of this article is to describe an analysis of pain management theory: a balance between analgesic and side effects based on Walker and Avant's method.

Key words: pain management, theory analysis

\section{PENDAHULUAN}

Nyeri adalah alasan umum yang membuat orang mencari pertolongan kesehatan. Pasien yang mengalami nyeri merasakan penderitaan dan berisiko mengalami efek jangka panjang yang tidak diharapkan seperti penyembuhan luka yang lama, penurunan sistem imun, dan metastasi sel tumor. Ada beberapa jenis nyeri yaitu: nyeri akut misalnya pada cidera, pembedahan, persalinan, krisis sel sabit; nyeri kronik pada gangguan muskuloskeletal atau gastrointestinal; nyeri karena prosedur misalnya pada lumbal pungsi, tusuk vena; nyeri kanker karena pembesaran tumor, metastasis, atau karena pengobatannya; nyeri pada bayi, penyakit kritis, dan pada akhir kehidupan.

Nyeri telah disepakati sebagai tanda vital yang kelima selain tekanan darah, nadi, pernapasan, dan suhu (Bertagnolli, 2004). Tenaga kesehatan bertugas dan kewajiban untuk mengidentifikasi nyeri, mengobati sumbernya, dan menguranginya.
Sedangkan para peneliti berkewajiban menguji berbagai intervensi untuk mengurangi nyeri.

Berbagai teori telah dikembangkan untuk menjelaskan dan mengelola nyeri, salah satunya adalah teori nyeri: keseimbangan antara analgesik dan efek samping merupakan teori yang dikembangkan oleh Marion Good (2004) dan termasuk dalam teori middle-range. Teori ini belum lama dikembangkan sehingga masih diperlukan analisis untuk mendapatkan pemahaman yang mendalam. Menurut Walker dan Avant (1995) tujuan analisis teori adalah untuk menentukan kelebihan dan kekurangan teori dan untuk menentukan kebutuhan pengembangan selanjutnya atau penyempurnaan teori. Analisis ini bermanfaat karena memberikan cara sistematik dan obkektif untuk menguji teori yang mungkin saja memberikan ide perumusan baru yang sebelumnya tidak terlihat.

Langkah-langkah analisis teori adalah: (1) 
menentukan asal teori, (2) menguji makna, (3) menganalisis kecukupan logika, (4) menentukan kemanfaatan, (5) menjelaskan tingkat kemampuan generalisasi dan parsimoni, dan (6) menentukan kemampuan teori ini untuk diuji. Tujuan penulisan artikel ini adalah memberikan gambaran analisis nyeri: keseimbangan antara analgesik dan efek samping berdasarkan langkah-langkah yang telah dirumuskan Walker dan Avant sehingga dapat disimpulkan kelebihan dan kekurangan teori tersebut.

\section{ANALISIS TEORI NYERI}

Beberapa hal penting terkait pengembangan teori perlu dijelaskan sebelum pembahasan analisis teori. Bermacam teori dalam pengembangannya dapat dikategorikan berdasarkan lingkup atau tingkat abstraksinya seperti metateori, teori grand, teori middle-range, dan teori mikro/ praktik. Sedangkan berdasarkan tujuannya, teori dapat dikategorikan menjadi teori deskriptif, teori eksplanatori, teori prediktif, dan teori preskriptif (McEwen \& Wills, 2007; McKenna, 1997).

Teori deskriptif(factor-isolating) menjabarkan, mengamati, serta memberi konsep, properti dan dimensi. Akan tetapi, teori deskriptif tidak memberikan penjelasan interelasi antara konsep atau proposisi dan tidak menunjukkan bagaimana perubahan dalam satu konsep mempengaruhi konsep yang lain. Teori eksplanatori (factorrelating) menghubungkan konsep ke konsep lain, menjabarkan serta menspesifikkan berbagai asosiasi atau interelasi antar konsep. Teori jenis ini juga menjelaskan dan bagaimana dan mengapa konsep tersebut terhubung dan dapat menemukan kausalitas, korelasi, dan aturan yang mengatur interaksi. Teori prediktif (situation-relating) menjabarkan presisi relasi antara konsep dan mensyaratkan eksistensi jenis teori yang lebih elementer sebelumnya. Teori ini merupakan hasil dari konsep yang didefinisikan dan relasi pernyataan yang dapat menjabarkan keluaran berikutnya secara konsisten.

Teoripreskriptif(situation-producing) dianggap merupakan tingkat tertinggi pengembangan teori. Teori ini menentukan kegiatan yang penting untuk mencapai tujuan definisi. Dalam keperawatan, teori preskriptif mengarah pada terapi keperawatan dan memprediksi konsekuensi intervensi. Tiga komponen dasar teori ini adalah tujuan atau keluaran yang spesifik, aktifitas yang eksplisit dilakukan untuk mencapai tujuan dan daftar survei yang menekankan pada dasar konseptual teori. Keluaran dari teori ini berupa norma atau standar.

Keperawatan sebagai profesi seharusnya berada di antara tingkat menjabarkan atau menjelaskan dan mengusahakan berada pada tingkat tertinggi yaitu prediktif dan preskriptif. Pembahasan mengenai analisis teori nyeri: keseimbangan antara analgesik dan efek samping akan mengikuti enam langkah menurut Walker dan Avant yang telah disebutkan sebelumnya.

\section{Asal teori nyeri: Keseimbangan antara analgesik dan efek samping}

Penentuan asal teori harus merujuk pada pengembangan asal teori. Hal yang telah diketahui adalah bahwa siapapun yang mengalami nyeri, yang dapat diidentifikasi hanyalah tentang bagaimana nyeri itu dirasakan. Profesi kesehatan yang mempelajari nyeri atau merawat orang dengan nyeri mungkin tidak mengalami nyeri serupa. Namun, mereka harus mempercayai apa yang dikatakan pasien tentang bagaimana nyerinya. Kualitas, intensitas, durasi, dan perjalanan nyeri bervariasi tergantung pada jenis dan orang yang mengalami nyeri. Teori ini bermula dari berbagai teori sebelumnya seperti teori tentang mekanisme nyeri, pergeseran dalam fokus ke penurun nyeri, pengembangan yang terintegrasi dan pendekatan preskriptif, dan pedoman manajemen nyeri akut.

\section{Teori mekanisme nyeri.}

Teori nyeri tertua digambarkan seorang filsuf, ahli matematika, dan fisiolog abad 17 yaitu Rene Descartes dalam gambarannya tentang seorang anak yang kakinya terlalu dekat dengan api.

Ia orang pertama yang mengemukakan sebuah 
hubungan antara sensasi perifer dan otak. Ketika merenungi koneksi pikiran-tubuh, Descartes menemukan bahwa sensasi yang menstimulasi tubuh disampaikan langsung ke otak, yang dipersepsikan sebagai nyeri. Sedangkan von Frey di tahun 1895 mempublikasikan tentang teori nyeri yang spesifik berkaitan dengan temuan adanya saraf khusus nyeri (Peterson \& Bredow, 2004; Yang $\& \mathrm{Wu}, 2001)$. Teori tersebut masih digolongkan pada teori deskriptif.

Teori yang terus digunakan hingga kini untuk menjelaskan nyeri adalah teori gerbang kendali (gate control theory). Pada tahun 1965, Melzack dan Wall (Strong, Unruh, Wright, \& Baxter, 2002) mempublikasikan teori yang dikenal dengan istilah gate control theory of pain, teori yang sangat dikenal di dunia keperawatan. Menurut teori ini, sebuah mekanisme di otak berbuat seperti sebuah gerbang untuk meningkatkan atau mengurangi aliran impuls saraf dari serat ke sistem saraf pusat. Gerbang yang "terbuka" memungkinkan aliran impuls saraf sehingga otak menerima pesan nyeri. Gerbang yang tertutup tidak memungkinkan saraf mengalirkan pesan nyeri ke otak sehingga nyeri tidak dipersepsikan. Teori lain yang juga digunakan adalah analgesik endogen yang muncul karena ditemukannya opiat endogen di daerah abu periakueduktal otak, reseptor opioid di susunan saraf pusat, dan kemudian serotonin dan reseptor neuropeptida.

Teori gate control dan analgesik endogen hanya merupakan teori deskriptif dan eksplanatori mekanisme nyeri yang berisi proposisi bagaimana nyeri terjadi dan bagaimana modulasinya di dalam tubuh. Kedua teori tersebut memberi pandangan baru kepada tenaga kesehatan bagaimana menghadapi nyeri yang memberi sugesti hubungan terapeutik tetapi tidak mengkhususkan intervensi yang efektif dan merupakan teori preskriptif. Teori preskriptif diperlukan disiplin keperawatan karena perawat melakukan intervensi untuk meningkatkan status kesehatan pasien (Good, 2004).

\section{Pergeseran dalam fokus ke penurun nyeri}

Ini termasuk teori eksplanatori dan preskriptif opioid dan non-opioid seperti lokal anestesi dan non steroid anti inflammatory drugs (NSAIDs). Para profesional kesehatan sudah mengetahui bahwa opioid yang diberikan secara oral, injeksi atau epidural memberikan efek penurun nyeri sedang dan berat yang poten (Hyllested, Jones, Pedersen, \& Kehlet, 2002).

\section{Pengembangan yang terintegrasi, pendekatan preskriptif}

Pergeseran paradigma ketiga adalah gagasan bahwa penurunan nyeri oleh perawat memerlukan pendekatan preskriptif yang terintegrasi dengan melibatkan pendidikan pasien, medikasi analgesik, metode non farmakologis, dan asuhan keperawatan spesialis (Good, 2004).

\section{Pedoman manajemen nyeri akut}

Teori ini dikembangkan dari Pedoman Manajemen Nyeri Akut oleh Agency For Health Care Policy And Research. Pedoman ini dikembangkan berdasarkan kesepakatan multidisiplin seperti peneliti, perawat, dan dokter anestesi. Pedoman ini memberikan dasar bagi pengembangan teori yang sedang dibahas ini.

Teori ini adalah teori preskriptif middle-range manajemen nyeri terintegrasi yang pertama. Konsep utama yang dikembangkan oleh teori ini adalah nyeri. Nyeri akut dikonsepkan sebagai fenomena multidisiplin yang terjadi setelah pembedahan atau trauma yang mencakup dimensi sensori dan afektif. Nyeri pada orang dewasa yang sadar adalah apa yang ia laporkan. Komponen sensori nyeri yang terjadi setelah kerusakan jaringan tubuh adalah persepsi fisik terhadap luka yang bersifat lokal. Komponen afektif nyeri adalah emosi yang tidak menyenangkan berkaitan dengan sensasi dan sudah dinamakan distres nyeri, kecemasan, atau sesuatu yang tidak menyenangkan. Kedua komponen ini saling mempengaruhi satu sama lain dan dapat diukur intensitasnya. Konsep dari teori ini dijabarkan secara lengkap pada pembahasan berikutnya.

\section{Makna}


Pengujian makna melalui tahap-tahap berikut yaitu yang identifikasi konsep, identifikasi definisi dan penggunaannya, identifikasi pernyataan, dan uji hubungan antara konsep seperti yang ditunjukkan dalam tabel 1 .

Muatan konsep dalam teori ini bervariasi dari yang abstrak ke konkret tetapi lebih banyak yang konkret. Definisi konsepnya pun walaupun 
Gambar 1 menunjukkan bahwa teori ini memiliki cukup logika. Menurut Liehr dan Smith (1999, dalam Peterson \& Bredow, 2004) pengembangan teori middle-range sesuai dengan proses intelektual dan sumber isinya adalah teori induktif, membangun teori melalui penelitian; teori deduktif, membangun dari teori grand atau model; mengkombinasi teori keperawatan dan non-keperawatan yang sudah ada sebelumnya; mensintesis teori dari publikasi hasil penelitian; serta mengembangkan teori dari pedoman praktik klinik.

Good (2004) pada bagian awal disebutkan bahwa ia mengembangkan teori ini bermula dari berbagai teori sebelumnya seperti teori tentang mekanisme nyeri, pergeseran dalam fokus pada penurun nyeri, pengembangan pendekatan yang terintegrasi, dan pedoman manajemen nyeri akut. Namun demikian, jika melihat gambar 1 maka teori ini juga bersifat deduktif. Keseimbangan antara analgesik dan efek samping adalah keluaran yang umum, sang teoris mendeduksi menjadi konsep keluaran spesifik.

Ini mungkin saja terjadi karena sifat teori middle-range memang memiliki kaitan langsung dengan penelitian dan praktik. Teori tersebut dapat dikembangkan secara induksi melalui penelitian kualitatif dan observasi praktik atau secara deduksi melalui analisis dan sintesis logis. Teori dapat juga diperoleh melalui proses retroduktif dari induksideduksi (Smith \& Liehr, 2008). Kesederhanaan teori dan adanya kongruensi antara konsep dan pernyataannya maka sejauh analisis yang sudah dilakukan penulis tidak menemukan adanya logical fallacies.

\section{Kemanfaatan}

Tiga isu perlu dilihat untuk menentukan kemanfaatan sebuah teori yaitu (1) berapa banyak penelitian telah dihasilkan teori, (2) untuk masalah klinik apa teori tersebut relevan, dan (3) sudahkah teori mempunyai potensi mempengaruhi praktik, pendidikan, administrasi keperawatan (Walker \& Avant, 1995). Jika teori memberikan pandangan baru dalam suatu fenomena, jika membantu ilmuwan menjelaskan fenomena lebih baik atau berbeda, atau jika membantu ilmuwan memprediksi lebih baik, maka dapat dikatakan bahwa teori tersebut bermanfaat.

Teori ini, seperti dijelaskan pada bagian sebelumnya, merupakan teori middle-range pertama yang berisi tentang manajemen nyeri integratif, artinya teori ini memberikan pandangan baru terhadap teori nyeri. Walaupun awal teori ini salah satunya dari pedoman praktik, tetapi teori ini memberikan gambaran yang lebih luas dan parsimonious (hemat). Teori ini dapat diterapkan pada banyak area yaitu praktik, pendidikan, maupun penelitian. Hal ini sesuai dengan Whall (1996) yang menyebutkan bahwa karakteristik teori middlerange yang baik adalah konsep dan proposisinya spesifik keperawatan, sudah siap dioperasionalkan, dapat diaplikasikan pada banyak situasi, rentang proposisinya dari kausatif ke asosiatif, tergantung pada aplikasinya dan asumsinya tepat.

Relevansi teori ini dengan masalah klinik sudah digambarkan di bagian pendahuluan bahwa nyeri merupakan masalah di semua area keperawatan. Teori ini juga akan memberikan perubahan pada sifat praktik yang lebih menggunakan pendekatan multidisiplin. Perspektif baru yang dibawa adalah bahwa praktik manajemen nyeri yang terbaik yaitu yang terintegrasi dengan mengkombinasikan medikasi analgesik dengan adjuvant non-farmakologis, asuhan keperawatan yang cermat, dan partisipasi pasien.

\section{Kemampuan generalisasi}

Kemampuan generalisasi dapat ditentukan dengan menguji batasan teori dan mengevaluasi penelitian yang mendukung teori (Walker \& Avant, 1995). Teori ini sebenarnya dapat diuji pada semua kondisi nyeri, meskipun sejauh ini masih terbatas digunakan pada penelitian tentang nyeri akut termasuk nyeri pascabedah baik pada dewasa maupun anak. Jenis nyeri lainnya seperti persalinan, nyeri pasca tindakan, nyeri kanker, dan sebagainya sejauh ini belum pernah dilaporkan menggunakan teori ini.

Teori ini spesifik ditujukan pada hal yang berkaitan dengan nyeri sehingga penggunaannya 
juga terbatas pada hal tersebut. Penggunaan teori ini dalam berbagai tatanan pelayanan selain di rumah sakit belum pernah dilaporkan.

\section{Parsimony}

Parsimony mengacu pada seberapa sederhananya atau kompleksnya teori dalam menjelaskan fenomenanya (Walker \& Avant, 1995). Teori ini digolongkan dalam middle-range sehingga sangat spesifik dan sederhana dalam menjabarkan suatu fenomena.

\section{Testabilitas}

Apakah teori ini cukup didukung oleh bukti atau tidak? Apakah teori ini dapat menghasilkan hipotesis? Sejauh ini karena teori ini tergolong baru maka masih terus diuji baik oleh penemu teori Good dan juga peneliti lainnya. Penelitian terkait nyeri yang saat ini terus diuji dan ditemukan penemuan baru adalah penelitian tentang pengukuran nyeri. Pengukuran nyeri dengan berbagai jenis alat ukur penting terkait dengan konsep utama ketiga teori ini yaitu asuhan keperawatan yang cermat yang berisikan antara lain pengkajian nyeri.

\section{KESIMPULAN}

Nyeri adalah pengalaman universal yang sudah diketahui sejak seseorang pengalami penyakit, persalinan, atau trauma. Walaupun nyeri telah dipelajari sejak berabad yang lalu, tetapi baru belakangan ini dipelajari dari perspektif keperawatan. Teori middle-range yang dibahas ini mencerminkan misi keperawatan terhadap intervensi yang efektif dan holistik untuk mengurangi nyeri, penderitaan, dan mencegah efek jangka panjang yang merugikan.

Kekuatan teori ini seperti halnya teori middlerange lainnya yaitu bersifat lebih konkret, cakupan lebih sempit, fenomena lebih spesifik, mewakili realitas pandangan keperawatan, menguji empiris lebih tepat, dan lebih dapat diaplikasikan langsung dalam praktik terutama yang berkaitan dengan manajemen nyeri. Middle-range juga cenderung berfokus pada konsep yang diminati perawat.
Nyeri ini juga melibatkan empati, kehilangan, harga diri, harapan, kenyamanan, martabat, dan kualitas hidup. Dasar pengembangan yang berasal dari penelitian-teori-praktik dapat mengurangi jarak perbedaan antara penelitian-praktik dan teoripraktik dan memberikan pengetahuan yang lebih siap diterapkan pada situasi perawatan langsung.

Kekurangannya adalah karena teori ini sangat terbatas sehingga bisa menjadi terlalu menfragmentasi pengetahuan keperawatan berdasarkan pada teori yang seringkali tidak terkait atau malah berbeda. Teori ini dikembangkan salah satunya melalui pedoman manajemen nyeri akut yang sudah ada tetapi pedoman tersebut bisa saja tidak dapat digeneralisasi untuk semua situasi termasuk di Indonesia karena sejauh ini belum ada kesepakatan multidisiplin dalam hal penanganan nyeri. Penerapan teori ini juga harus mempertimbangkan aspek lain di luar konsep utama yang mungkin secara sistem dan institusional mempengaruhi manajemen nyeri seperti situasi sosial-ekonomi, nilai, dan budaya (ENT, HP).

* Staf Akademik Keperawatan Maternitas FIK UI

\section{KEPUSTAKAAN}

Bertagnolli, A. (2004) Pain: the $5^{\text {th }}$ vital signt. Patient Care, 9, 66-70.

Good, M. (2004). Pain: A balance between analgesia and side effects. In S.J. Peterson \& T.S. Bredow. (Eds). Middle range theories: Application to nursing research. Philadelphia: Williams \& Wilkins.

Hyllested, M., Jones, S., Pedersen, J.L. \& Kehlet, H. (2002). Comparative effect of paracetamol, NSAIDs or their combination in postoperative pain management: A qualitative review. British Journal of Anaesthesia, 88 (2 ), 199-214.

McEwen, M. \& Wills, E.M. (2007). Theoretical basis for nursing. $2^{\text {nd }}$ ed. Philadelphia: Lippincott Williams \& Wilkins.

McKenna, H.P. (1997) Nursing models and theories. London: Routledge, p. 144-146. 
Peterson, S.J \& Bredow, T.S. (eds). (2004). Middle range theories: Application to nursing research. Philadelphia: Williams \& Wilkins.

Smith, M.J. \& Liehr, P.R. (eds). (2008). Middle range theory for nursing. $2^{\text {nd }} e d$. New York: Springer Publishing Company.

Strong, A. M., Unruh, A., Wright, \& Baxter, D. (ed). (2002). Pain: A textbook for therapist. London: Churchill.

Walker, L.O., \& Avant, K.C. (1995). Strategies for theory construction in nursing. $3^{\text {rd }} \mathrm{ed}$. Norwalk: Appleton \& Lange.

Whall, A. (1996). The structure of nursing knowledge: Analysis and evaluation of practice, middle-range and grand theory. In
Models of Nursing: Analysis and Application. ( $3^{\text {rd }}$ ed ). Stanford, CT: Appleton \& Lange.

Yang, J \& Wu, C. (2001). On the neurobiology of pain, American Scientist http://www. americanscientist.org, diperoleh $25 \mathrm{Mei}$ 2008. Fitzpatrick J \& Whall, A, eds. Conceptual

Pengetahuan tidaklah cukup; kita harus mengamalkannya. Niat tidaklah cukup; kita harus melakukannya.

(Johann Wolfgang von Goethe)

Raihlah ilmu, dan untuk meraih ilmu belajarlah untuk tenang dan sabar.

('Umar Bin Khattab)

Ilmu pengetahuan tanpa agama adalah pincang.

(Albert Einstein)

Jenius adalah $1 \%$ inspirasi dan $99 \%$ keringat. Tidak ada yang dapat menggantikan kerja keras. Keberuntungan adalah sesuatu yang terjadi ketika kesempatan bertemu dengan kesiapan.

( Thomas A. Edison)

Sumber kekuatan baru bukanlah uang yang berada dalam genggaman tangan beberapa orang, namun informasi di tangan orang banyak. 